\title{
Cystic appearance: an uncommon feature of pulmonary metastasis of colorectal origin
}

\author{
Nicolae Irinel Simion, Edgardo Pezzetta \\ General Surgery Department, Riviera Hospital, Montreux, Switzerland
}

Correspondence to Dr Nicolae Irinel Simion, irisnicol@gmail.com

\section{DESCRIPTION}

A 46-year-old male has a recent history of rectal adenocarcinoma ypT3N1M0G2, treated by neoadjuvant radiochemotherapy, low anterior rectal resection and adjuvant chemotherapy. Before surgery a thoraco-abdominal CT showed no other pathological lesion. The patient presented free of symptoms 6 months after surgery for follow-up visit, had no fever and normal values at routine laboratory evaluation. The thoraco-abdominal CT identified a cystic lesion with thin wall in the apical segment of the right inferior lobe of $2.5 \mathrm{~cm}$ diameter, not seen at previous radiological assessment (figure 1), with no thoracic lymphadenopathy and without signs of abdominal disease; it was considered that colonoscopy was not necessary at the time. The cystic lesion was interpreted initially of unknown origin, the patient presenting neither inflammatory signs nor respiratory symptoms. His metastatic origin could not be ruled out at the time, the carcinoembryonic antigen being normal. The patient was followed strictly and 6 months later a new CT (figure 2) showed growth in size of the lesion that appeared with a thicker wall, both features sustaining the metastatic probability. There was no liver metastasis at CT and colonoscopy at 1 year after surgery found no local recurrence. Cardiopulmonary tests were normal without contraindication of thoracic surgery.

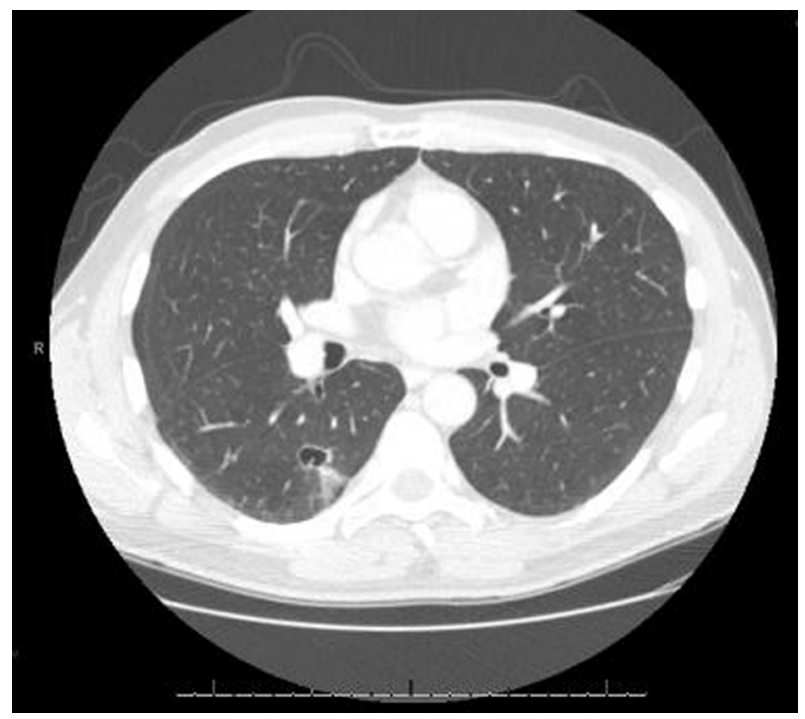

Figure 1 Cystic pulmonary lesion in the right inferior lobe appeared 6 months after rectal surgery.
The patient had right thoracotomy and wedge resection of the pulmonary lesion. The pathological examination revealed a metastasis of adenocarcinoma of colorectal type, without infiltration of the pleura and with $50 \%$ viable cells, negatives for cytokeratin 7 and thyroid transcription factor- 1 at immunohistochemistry. The patient had another regimen of adjuvant chemotherapy (six cycles) by 5 -fluorouracil, leucovorin and avastin, even if the treatment was already completed previously following the international consensus for the stage of the colorectal cancer. At 1 year follow-up, the patient was free of symptoms and without radiological evidence of metastatic disease (figure 3). Cystic lung lesions can be caused by a diverse array of pathologic processes. Evaluating a patient with such lung lesions is helpful to distinguish cysts from cavities and to categorise focal or diffuse distribution. Cysts are defined as air-containing spaces surrounded by a thin wall (4 $\mathrm{mm}$ or less) while cavities are air-containing spaces with walls that are at least $5 \mathrm{~mm}$ thick. ${ }^{1}$ One of the most important distinctions in the differential diagnosis of cystic or cavitary lung lesions is the distinction between malignant and benign aetiologies. Primary lung cancer is a common disease, cavitation being detected by CT for up to $22 \%$ of primary lung cancers but for near $11 \%$ by plain thoracic radiography. Cavitation

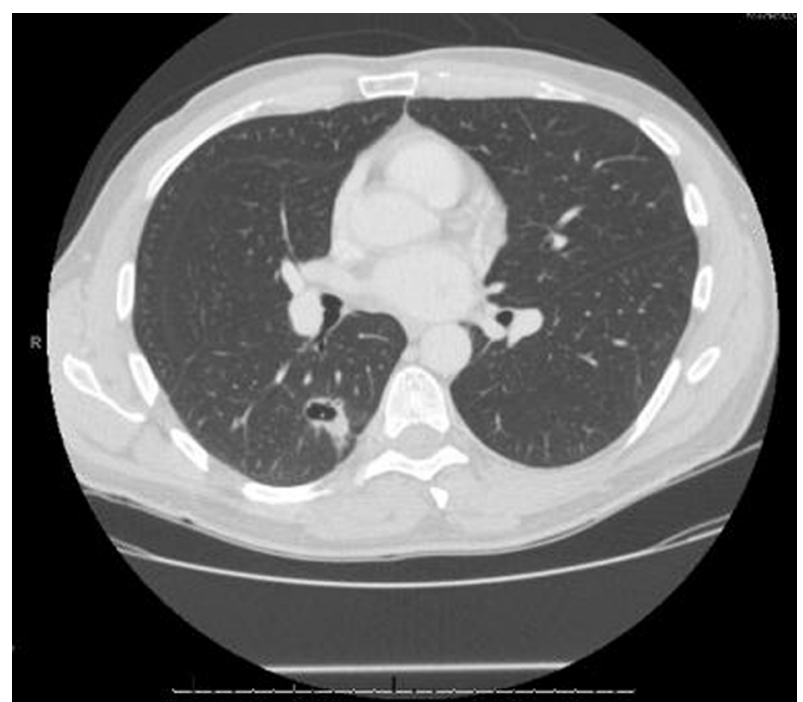

Figure 2 The cystic lesion has grown in size in the following 6 months, sustaining the metastatic origin. 


\section{BMJ Case Reports}

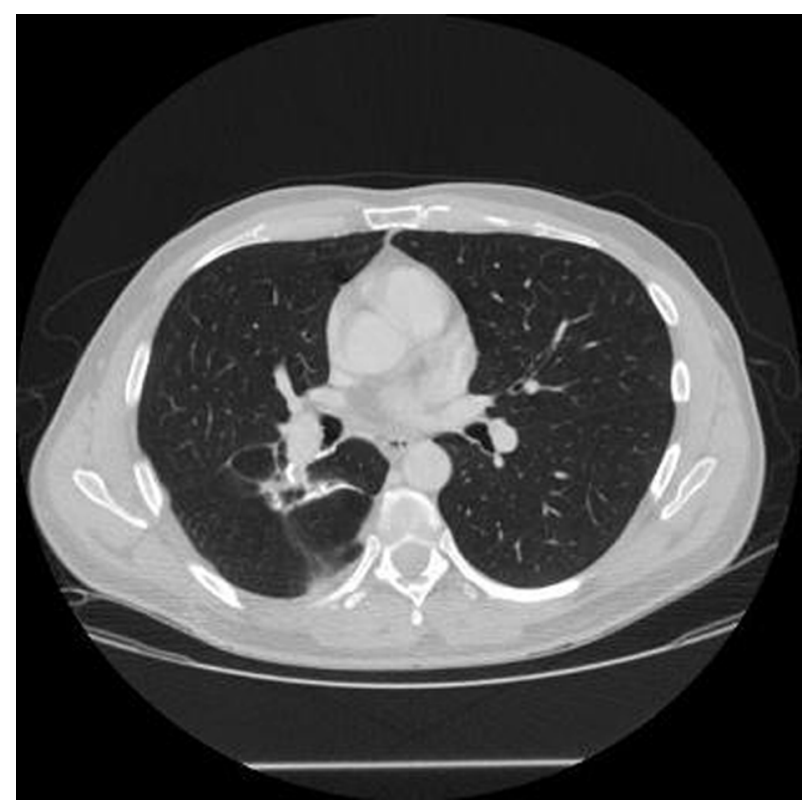

Figure 3 CT of the thorax at 1 year after lung metastasectomy showing scars and staples at the operated area in the right lung.

more frequently occurs in squamous cell carcinomas than in other histological type. Furthermore, the presence of cavitation in a lung tumour has been associated with a worse prognosis. Other primary tumours in the lung, such as lymphoma and Kaposi's sarcoma, may also present with cavitary lesions, particularly among persons infected with human immunodeficiency virus. ${ }^{2}$ Metastatic lung disease may also have a cavity or cystic appearance, but less frequently than in primary lung cancers: between metastatic tumours less than $5 \%$ were found cavitary by plain radiography. Metastatic tumours of squamous cell origin are more likely to cavitate than tumours of other origins, suggesting a common pathogenesis for cavitation among these tumours. ${ }^{2}{ }^{3}$ Infections caused by commonly encountered bacteria may cause pulmonary cavities by one of two mechanisms. First, organisms may enter the respiratory cavity via the upper airway and cause either a necrotising pneumonia or lung abscess. Alternatively, organisms may enter the lung via the bloodstream, often in association with fibrin and platelets as septic pulmonary emboli. ${ }^{2}$ Complicating the diagnostic evaluation of cavitary lung lesions there are several reports that have revealed the coexistence of pulmonary malignancy and an infectious pathogen. Non-infectious inflammatory processes associated with cystic pulmonary lesions include various vasculitides such as Wegener granulomatosis and rheumatoid nodules. Pulmonary embolism can also causes cystic lesions especially in immunosuppressed patients, even if infarction is found in less than $15 \%$ of cases, and only about $5 \%$ of infarctions cavitate. ${ }^{1}$ In our case, the patient had previous oncologic history and few risk factors for a primary lung tumour. The infectious origin was not sustained by biological tests and in spite of the rarer presentation; the metastatic origin was our first diagnosis considering the patient's situation. In conclusion, even the spectrum of pathological processes associated with pulmonary cavities and cysts is extremely large, narrowing that the differential diagnosis can be facilitated by a careful review of the patient's history and imaging data, making the clinical context as the most useful diagnostic tool.

\section{Competing interests None.}

Patient consent Obtained.

\section{REFERENCES}

1. Ryu JH, Swensen SJ. Cystic and cavitary lung diseases: focal and diffuse Mayo Clin Proc 2003:78:744-52.

2. Gadkowski LB, Stout JE. Cavitary pulmonary disease. Clin Microbiol Rev 2008;21:305-33.

3. Godwin JD, Webb WR, Savoca CJ, et al. Multiple, thin-walled cystic lesions of the lung. AJR Am J Roentgenol 1980;135:593-604.

This pdf has been created automatically from the final edited text and images.

Copyright 2011 BMJ Publishing Group. All rights reserved. For permission to reuse any of this content visit http://group.bmi.com/group/rights-licensing/permissions.

BMJ Case Report Fellows may re-use this article for personal use and teaching without any further permission.

Please cite this article as follows (you will need to access the article online to obtain the date of publication).

Simion NI, Pezzetta E. Cystic appearance: an uncommon feature of pulmonary metastasis of colorectal origin. BMJ Case Reports 2011; 10.1136/bcr.10.2011.5063, Published XXX

Become a Fellow of BMJ Case Reports today and you can:

- Submit as many cases as you like

- Enjoy fast sympathetic peer review and rapid publication of accepted articles

- Access all the published articles

- Re-use any of the published material for personal use and teaching without further permission

For information on Institutional Fellowships contact consortiasales@bmjgroup.com

Visit casereports.bmj.com for more articles like this and to become a Fellow 